\title{
CHANGES IN BASAL BODY TEMPERATURE AND SIMPLE REACTION TIMES DURING THE MENSTRUAL CYCLE
}

\author{
Nataša ŠIMIĆ ${ }^{1}$ and Arijana RAVLIĆ ${ }^{2}$ \\ Department of Psychology, University of Zadar, Croatia ${ }^{1}$, Department of Psychology, Faculty of Philosophy, \\ University of Mostar, Bosnia and Herzegovina ${ }^{2}$ \\ Received in October 2011 \\ CrossChecked in December 2012 \\ Accepted in October 2012
}

\begin{abstract}
Previous studies have shown cyclic changes in the activation levels and performance of different tasks throughout the menstrual cycle. The aim of this study was to examine if changes in the reaction time to both light and sound stimuli may be associated with basal body temperature changes and subjective assessments of General and High Activation during the different phases of a menstrual cycle characterized by high (preovulatory and midluteal phase) and low (menstrual and early follicular phase) levels of oestrogen and progesterone. The study included measurements of basal body temperature, simple reaction times to light and sound and self-assessment of General and High Activation during the menstrual, early follicular, late follicular and luteal phase.

The sample consisted of 19 female subjects with regular menstrual cycles. The results obtained in this study indicate lower basal body temperature values during phases with low sex hormone levels, while the activation assessments suggest stable levels of both General and High Activation throughout the menstrual cycle. Similar patterns of change have been shown for reaction times in visual and auditory sensory modalities. Reaction times were shorter during phases characterized by high sex hormone levels, while phases with low hormone levels were associated with longer reaction times. From the modified text on correlations in the data analysis section, it is evident that they were calculated from averaged data from all phases of the menstrual cycle. Therefore, they do not reflect intraindividual but rather interindividual variations between the observed variables, and are not related to the hypotheses of this paper.
\end{abstract}

KEY WORDS: activation level, AD-ACL list, light and sound stimuli, sex hormones

A menstrual cycle includes cyclic changes in sex hormone levels. Low levels of oestradiol and progesterone are present during the menstrual phase, while the follicular phase is characterized by a gradual increase in oestradiol levels, which culminates in the preovulatory period, on day 12 of a menstrual cycle. The central point of a menstrual cycle is ovulation, which occurs between days 10 and 14. It is controlled by the pituitary gland, which increasingly excretes the follicle-stimulating hormone (FSH) and luteinizing hormone (LH), followed by a higher amount of oestradiol from the follicles (1). During this period, basal body temperature values increase (2). After ovulation, oestradiol levels are lower, but progesterone levels start to increase. The luteal phase is characterized by high levels of oestradiol and progesterone, both of which culminate on day 22 (3). During the premenstrual phase, sex hormone levels are low (1), followed by a decrease of basal body temperature values (2) (Figure $1)$. 

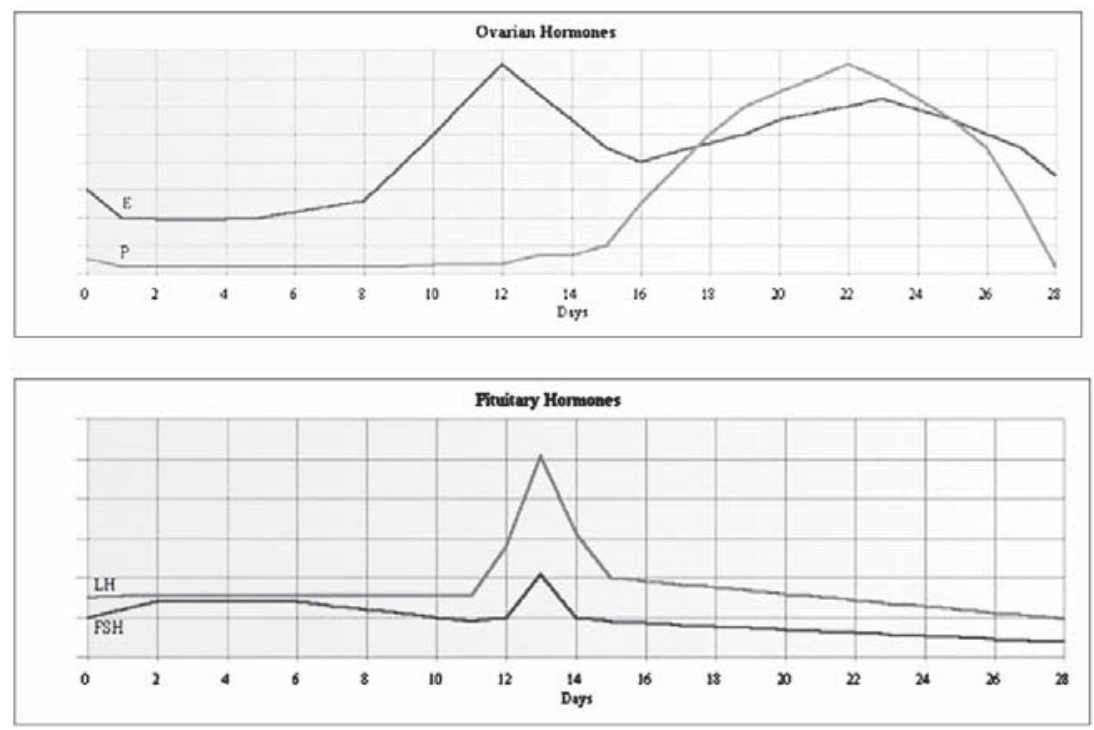

Figure 1 Ovarian and pituitary hormones during the menstrual cycle (14)

E-Oestradiol; P-Progesterone; LH-Luteinizing Hormone; FSH-Follicle stimulating hormone

Sex hormones modulate neural functioning through receptors distributed throughout the different parts of the central nervous system and by influencing different neurotransmitter systems. Through influencing the cholinergic, dopaminergic and serotonergic systems, sex hormones regulate mood, cognitive processes and various behavioural patterns (4). The effects of oestrogen on sensorimotor functions are attributed to its interaction with the dopaminergic system, an important factor in movement regulation (5). Involved in the neuromodulation of the serotonergic system, oestrogens increase degradation of monoamine-oxidase (the enzyme which catabolizes monoamines), multiply the number of serotonergic receptors, and accelerate the re-uptake of serotonin within a synapse $(4,6)$. The excitation effects of oestrogens are explained by their effects on glutamate, excitation neurotransmitters excreted from the cortical neurons $(5,7)$. Throughout the various parts of the central nervous system, two types of oestrogen receptors were identified (8). Alpha-type receptors prevail in the amygdala nuclei, while higher concentrations of beta-type receptors were found in the hippocampus $(8,9)$. The effects that oestrogens have on human neural processing are much more examined and documented than those of progesterone. Experiments involving animals indicate that progesterone metabolites increase activity of GABA $(7,10)$. Some authors have also reported low levels of GABA in the occipital cortex during the follicular phase, when progesterone levels are low, and increased
GABA levels during the luteal phase, when the excretion of progesterone increases (11).

The interaction between sex hormones and neurotransmitter systems may result in cyclic changes in activation levels throughout the menstrual cycle. This is substantiated by results from previous studies, which report that the activation of the autonomic nervous system is higher when sex hormone levels are low, while central nervous system activation improves during the period of higher hormone levels (12). Some studies of different measures of activation showed similar results. For example, monitoring cardiovascular activity across the menstrual cycle has shown that the lowest heart rates were found during the follicular and ovulatory phase, and increased to the highest values in the premenstrual and menstrual phases of a cycle $(13,14)$. Some studies have confirmed similar variations in the subjective assessments of activation during the menstrual cycle $(15,16)$. High Activation partly reflects anxiety and negative emotions that were found to be more expressed during the menstrual phase of a cycle $(8$, 14, 17, 18).

According to the classic arousal theory, individual efficiency in task performance is determined by the activation level. In general, the relationship between arousal and performance is a so-called "inverted Ushaped" function, according to which both low and high levels of arousal are associated with poorer processing of information, whilst medium levels of arousal are considered optimal for functioning (19). 
Based on this theory, it is anticipated that, during states of optimal arousal, the performance of simple tasks such as reaction time tasks may be improved. According to some studies, efficiency in reaction time tasks improves during phases of higher hormone levels $(13,14,20,21)$.

Studies which included measuring hormone levels during different phases of a menstrual cycle and employed sequential movement tasks showed that higher levels of oestradiol significantly correlate with shorter movement time, but that the correlation with total reaction time, including both decision time and movement time, was not significant (5).

Changes in other sensory systems throughout the menstrual cycle were also examined. A lower olfactory threshold was associated with the period of ovulation $(22,23)$, while the thermal cold perception threshold appeared to be lower at the late follicular and midluteal phase compared with the early follicular phase (24). A higher pain threshold was documented during the middle follicular phase (25).

Significant efficiency fluctuations were documented in performing different psychomotor tasks throughout the menstrual cycle. In tasks that required fine motor skills, the highest efficiency was found during phases characterized by high levels of oestradiol (late follicular phase) as well as high levels of both oestradiol and progesterone (midluteal phase) $(3,16)$. Results also indicated an improved performance of perceptual, as well as finger dexterity, tasks during phases of higher levels of oestradiol and both oestradiol and progesterone (late follicular and midluteal phase) compared with the menstrual phase, when levels of sex hormones are low $(3,18,26,27)$.

Previous studies have included examinations of reaction time to visual stimuli, while psychomotor reactions to sound stimuli seem to remain unexplored. However, oestradiol effects on the auditory system are documented in some animal studies $(28,29)$. Oestrogen receptors have been identified in the central auditory system during different periods of maturation in mice (28), as well as in the internal ear, including I - type cells of cochlear ganglion in humans and animals (29). As modulators of GABA-ergic, serotonergic and glutaminergic systems, oestrogens can also influence auditory functions on different levels of the central nervous system (29). Progesterone released from the corpus luteum during the luteal phase is the precursor of other steroid hormones and acts as a neurosteroid. Despite the fact that specific progesterone receptors have not been identified in the auditory system, this hormone may also affect auditory processing by influencing other steroid receptors (glucocorticoid and mineralocorticoid) located in the cochlea and other more proximal areas of the auditory system (29). Progesterone and its metabolites may also influence the auditory system as agonists of GABA-A. In general, progesterone has a mainly inhibitory impact on the central nervous system which may balance the mainly excitatory action of oestrogen (29). Some studies have also documented changes in auditory event-related potentials across the menstrual cycle, with more prominent changes occurring during the luteal phase (30). These results indicate lower orienting responses in the luteal phase that further manifest the involuntary cortical arousal response (30).

The basal body temperature measure is an important indicator of ovulatory cycles. Monitoring fluctuations in this variable has shown a significant correlation with the increase of gonadotropin levels controlled by the pituitary gland and a postovulatory increase in oestradiol and progesterone (2). Body temperature is also one of the most valid and sensitive indicators of general activation (19), therefore similar changes with other measures indicating activation variations are to be expected.

The aim of this study was to examine if changes in simple reaction time to light and sound can be associated with changes in basal body temperature and a subjective assessment of General and High Activation during menstrual cycle phases characterized by both low (menstrual and early follicular phase) and high (preovulatory and midluteal phase) levels of sex hormones. As a result of the different levels of arousal, efficiency fluctuations may be expected in simple reaction time tasks, as well as variations in basal body temperature and subjective measures of General and High Activation. Higher levels of activation as well as better task performance are expected during phases of higher sex hormone levels in comparison with phases when levels of sex hormones are low. Similar patterns of change can be expected for reaction times in both sensory modalities (visual/auditory). However, no differences in these variables are expected between the menstrual phase and early follicular phase, since both are characterized by low levels of sex hormones. Considering that the preovulatory phase is characterized by a higher level of oestradiol, and the luteal phase is characterized by an increase of both oestradiol and progesterone, possible efficiency differences may be attributed either to oestrogens or the interactive effects of oestrogens and progesterone. 


\section{SUBJECTS AND METHODS}

A group of 24 healthy females aged between 18 and 24 years $(M=20.2$ years; $s d=1.6$ years $)$ volunteered for the study. The subjects declared that they had normal and regular menstrual cycles $(28+/-2)$ days with $(5+/-2)$ days duration of menstrual bleeding in the last six months. Subjects confirmed that they had never given birth and had not used oral contraception in the previous six months. All were right-handed and were not on any medication during the time of the examination.

The subjects measured their own basal body temperature orally at a given time, immediately upon waking up and before getting up in order to study their ovulatory cycle, which was confirmed by a postovulatory increase in body temperature values.

Three subjects were not included in the data analysis because of incomplete basal body temperature measurements. Two subjects were excluded since the onset of their next menstrual cycle indicated a shorterthan-expected cycle. Therefore, data obtained from 19 subjects was ultimately analysed in this study.

\section{Instruments}

\section{AD-ACL list}

A modified Croatian version of Thayer's ActivationDeactivation Adjective List (AD-ACL), was used for assessments of General and High Activation (19). It consists of 14 adjectives describing activation states. The subject's task is to rate each activation state on a five degree scale with the following description of points: 1 - definitely do not feel, 3 - feel quite a bit, 5 - definitely feel, in accordance with their current state or mood.

Ratings for five adjectives (energetic, active, tired, lively, sleepy) are used to calculate a composite score of the dimension of General Activation, while nine adjectives (still, clutched up, calm, wakeful, intense, jittery, placid, fearful, tense) are used to calculate the score of the dimension of High Activation. Prior to calculation of the sum scores for each dimension, the ratings for five adjectives (tired, sleepy, still, calm and placid) were scored in the reverse order.

The factor analysis study involving the sample of students confirmed a two-factor structure reported by the author of this scale (19). The Internal consistency coefficient (Cronbach alpha) for general activation is 0.86 , while for high activation it is 0.80 (19).

\section{Reaction time task}

To examine the simple reaction time to light and sound, a standard apparatus made by Lafayette was used. It consisted of two units, a device for stimuli settings and another for stimuli response, along with an electronic chronometer for measuring the reaction time in milliseconds.

During each examination procedure, the subject was seated in front of a desk with the responding device placed on top of it. The task was to place the forefinger of the dominant hand on the central button, and as soon as the stimulus appeared, press the appropriate button. Each subject was told which stimulus to respond to (sound/light). In order to avoid the anticipation of a stimulus, the examiner varied the intervals between successive stimuli.

Each experimental situation consisted of ten trials, from which the arithmetic mean was calculated and represented as an individual reaction time expressed in milliseconds.

\section{Procedure}

Each subject was examined through four phases: menstrual phase (day 2), early follicular phase (day 7), late follicular phase (day 12) and midluteal phase (day 22). The subjects were examined during the morning hours (9 to $12 \mathrm{am}$ ), always at the same given time for each individual subject.

Examinations were not conducted during the first day of a menstrual cycle, because of the possible use of analgesics.

Every examination started with the subjects responding to the AD-ACL list and followed by an examination of simple reaction time to light and sound. The experimental order for setting different stimuli (light/sound) in different phases was rotated in ABBA design.

\section{Data analysis}

Statistica 7.00 was used for data analysis. An analysis of variance (ANOVA) for repeated measures on one factor (four phases of menstrual cycle) was used to test the significance of change between the phases. Significant effects were further analysed using Scheffe's post-hoc test. Dependent variables included basal body temperatures, assessments of General and High Activation and reaction times in visual and auditory sensory modalities. 


\section{RESULTS}

The repeated ANOVA measure indicated significant changes in body temperature throughout the menstrual cycle $(F(3 / 54)=31.00 ; p<0.05)$. Scheffe's test showed significant differences neither between the menstrual and early follicular phase $(p>0.05)$, nor between the late follicular and luteal phase $(p>0.05)$. However, there were significant differences between phases with high hormone levels and those characterized by low levels of hormones $(p<0.05)$. Figure 2 shows that the average temperature value during the menstrual and follicular phase is low, corresponding with the low level of sex hormones. As expected, significantly higher temperature values were found during phases of higher levels of sex hormones (late follicular and luteal phase).

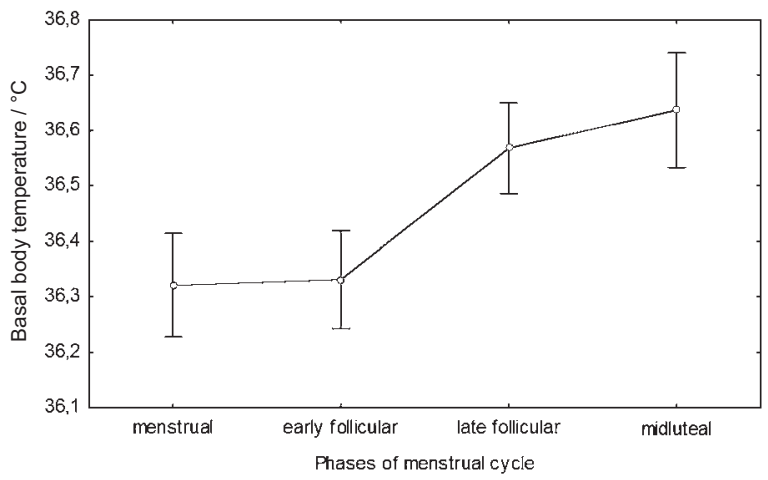

Figure 2 Basal body temperature through menstrual cycle phases (M $\pm S E)$

There were no significant changes either in General $(F(3 / 54)=1.44 ; p>0.05)$ or High Activation $(F(3 / 54)=0.20 ; p>0.05)$ during different menstrual cycle phases (Figures 3-4).

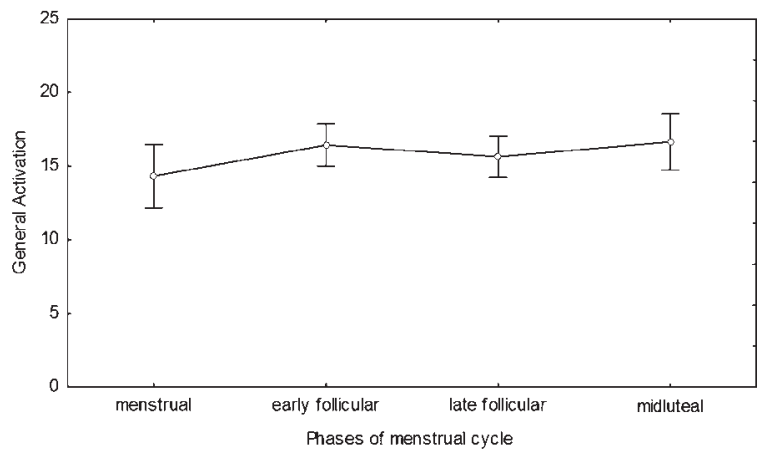

Figure 3 General Activation levels through menstrual cycle phases ( $M \pm S E)$

Changes in reaction times showed significant phase effects, both in the visual $[F(3 / 54)=4.36 ; p<0.05]$, and

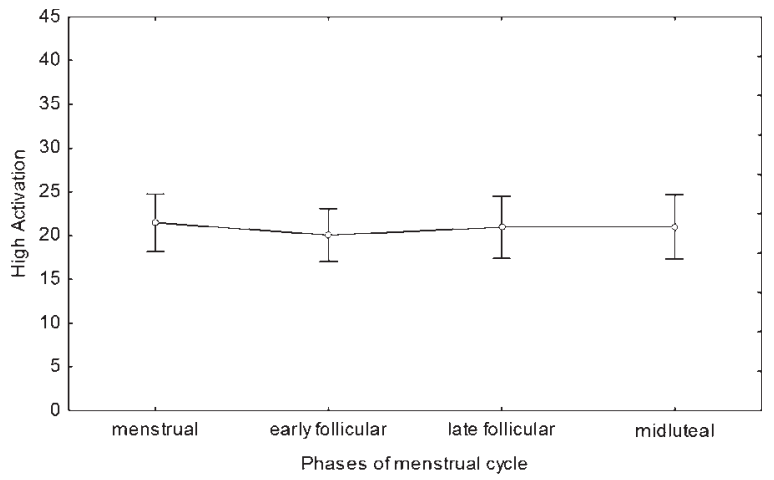

Figure 4 High Activation levels through menstrual cycle phases $(M \pm S E)$

auditory $[F(3 / 54)=6.24 ; p<0.05]$ modality. Scheffe's post-hoc test indicates that differences are significant between the menstrual and late follicular phase $(p<0.05)$, as well as between the early and late follicular phase $(p<0.05)$. Therefore, reaction time to light is significantly longer at the menstrual and early follicular phase in comparison with the late follicular phase (Figure 5). As expected, both the difference between the menstrual and early follicular phase $(p>0.05)$ and the difference between the late follicular and luteal phase are not significant. A similar pattern of change was demonstrated throughout the menstrual cycle for the reaction time to sound. As expected, no significant difference was found either between the menstrual and early follicular phase, when levels of sex hormones are low, or between the late follicular and luteal phase, when hormone levels are high. However, post-hoc analysis revealed significant differences between the menstrual and luteal phase $(p<0.05)$, as well as between the early follicular and luteal phase $(p<0.05)$. Thus, the reaction time to sound is shorter at the luteal phase in comparison with the menstrual and early follicular phase (Figure 5).

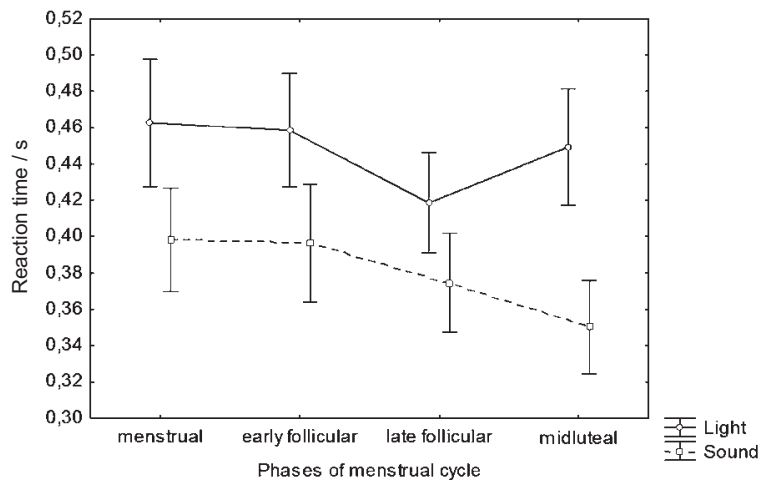

Figure 5 Simple reaction times through menstrual cycle phases $(M \pm S E)$ 


\section{DISCUSSION}

The results obtained in this study indicated significantly lower values of basal body temperature during the first half of the cycle, when sex hormones levels are low, and higher temperature values during the second half of the cycle, when hormonal levels are high. These results confirmed those from previous studies $(2,14)$, which have shown that the postovulatory temperature increases and confirmed established relationships between body temperature and hormonal changes during the menstrual cycle. Earlier studies have also shown that rectal temperature increases by $0.4{ }^{\circ} \mathrm{C}$ during the luteal phase compared with the follicular phase of a menstrual cycle (31). Post-ovulatory increases in body temperature are attributed to the anabolic effects of progesterone and are therefore considered a sign that ovulation has occurred (32).

With regards to the subjective self-assessment of activation, the results obtained in this study have not shown significant changes during the menstrual cycle, indicating a relatively stable level of General and High Activation throughout the different phases of a cycle. Although it was expected that activation levels would change throughout the menstrual cycle, this finding has neither confirmed expectations nor has it proven consistent with some previous studies $(12,15,16)$ that had also included self-assessment measures of activation. Considering that subjective assessments can be governed by the interaction effects of circumstances and personality traits, future studies should give priority to objective activation level indicators (heart rate, blood pressure, electrodermal reactions) that also give insight into the activity of the autonomic system.

This study also found significant differences in reaction time to light and sound during different phases of a menstrual cycle. As expected, considering the hormonal fluctuations during the menstrual cycle, we found that reaction times are longer during phases when hormone levels are low (menstrual and early follicular phase). There was a similar pattern of change for reaction times in both modalities, including the shortest reaction times during phases when hormone levels are high. A vast majority of previous studies also indicate better efficiency in the so-called intermenstrual period of the cycle (from the preovulatory to luteal phase) $(2,3,21,27)$. A correspondence regarding poorer efficiency in the menstrual phase has also been documented in the relevant literature, but lacks comparison between phases with low levels of hormones. Simple reaction time to light was examined in a previous study (14) and has appeared to be the shortest in the follicular and ovulatory phases, which is in accordance with results obtained in the present study. Similar results were also obtained in a study by Zajdel and Nowak (33), which examined simple reaction times to visual stimuli. Simple reaction times to sound have not been examined in previous studies, while this study shows them to be shortest in the luteal phase. On the basis of insignificant differences for reaction times between the late follicular and luteal phases in both modalities, it can be asserted that phases with higher levels of hormones are associated with higher efficiency. Previous studies have also shown that a higher level of oestradiol was associated with shorter movement time in performing reaction time tasks (5). A study that included hormonal level measures demonstrated a significant correlation between reaction time and oestradiol level $(r=0.50)$, while the correlation between progesterone level and reaction time in stopsignal tasks was not significant (34).

Future studies of menstrual cycle effects should include an examination of activation levels and efficiency during the menstrual cycle involving introverts and extraverts with different levels of arousal (42).

\section{CONCLUSION}

In conclusion, it may be said that the results obtained in this study show a longer simple psychomotor reaction time to light and sound during the menstrual and early follicular phase, in which low temperature values were also documented. During phases of higher levels of sex hormones (preovulatory and midluteal phase), shorter reaction times and higher body temperature were found. Significant variations of reaction time throughout a menstrual cycle indicate changes in the speed of neural processes in the central nervous system and should be taken into account when conducting behavioural and neuropsychological assessments of women.

\section{REFERENCES}

1. Pinel JPJ. Biološka psihologija [Biological Psychology, in Croatian]. Jastrebarsko: Naklada Slap; 2002. 
2. Beaudoin J, Marrocco R. Attentional validity effects across the human menstrual cycle varies with basal temperature changes. Behav Brain Res 2005;158:23-9.

3. Hampson E, Kimura D. Reciprocal effects of hormonal fluctuations on human motor and perceptual-spatial skills. Behav Neurosci 1988;102:456-59.

4. Sherwin BB. Estrogen and cognitive functioning in women. Endocr Rev 2003;24:133-51.

5. Jennings PJ, Janowsky JS, Orwoll E. Estrogen and sequential movement. Behav Neurosci 1998;112:154-9.

6. Sherwin BB. Estrogen and mood in women. Endocrinologist 2005; 15:180-5.

7. Smith MJ, Keel BA, Greenberg BD, Adams BA, Schmidt PJ, Rubinow DA, Wassermann EM. Menstrual cycle effects on cortical excitability. Neurology 1999;53:2069-72.

8. Genazzani AR, Stomati M, Morittu A, Bernardi F, Monteleone P, Casarosa E, Gallo R, Salvestroni C, Luisi M. Progesterone, progestagens and the central nervous system. Hum Reprod 2000;15(Suppl 1):14-27.

9. Osterlund MK, Hurd YL. Estrogen receptors in the human forebrain and the relation to neuropsychiatric disorders. Prog Neurobiol 2001;64:251-67.

10. Wirth MM, Meier EA, Fredrickson BL, Schultheiss OC. Relationship between salivary cortisol and progesterone levels in humans. Biol Psychol 2007;74:104-7.

11. Epperson CN, Haga K, Mason GF, Sellers E, Gueorguieva $\mathrm{R}$, Zhang W. Cortical $\gamma$-aminobuturic acid levels across the menstrual cycle in healthy women and those with premenstrual dysphoric disorder. Arch Gen Psychiatry 2002;59;851-8.

12. Asso D, Braier JR. Changes with menstrual cycle in psychophysiological and self-report measures of activation. Biol Psychol 1982;15:95-107.

13. ProrokovićA, Gregov Lj. Changes in some psychophysiological variables during menstrual cycle. Med Jad 1997;1:5-17.

14. Šimić N, Manenica I. Promjene nekih psihofizioloških varijabli tijekom menstrualnog ciklusa [Changes in some psychophisiological variables during the menstrual cycle, in Croatian]. Radovi Filozofskog fakulteta u Zadru 1998;36:7990.

15. Hartley LR, Lyons D, Dunne M. Mamory and menstrual cycle. Ergonomics 1987;30:111-20.

16. Symonds CS, Gallagher P, Thompson JM, Young AH. Effects of the menstrual cycle on mood, neurocognitive and neuroendocrine function in healthy premenopausal women. Psychol Med 2004;34:93-102.

17. Šimić N. Neuroticizam i psihofiziološke promjene tijekom menstrualnog ciklusa [Neuroticism and psychopysiological changes during the menstrual cycle, in Croatian]. Med Jad 1999;29:5-20.

18. Šimić N, Tokić A, Peričić M. Performance of fine motor and spatial tasks during the menstrual cycle. Arh Hig Rada Toksikol 2010;61:407-14.

19. Proroković A. Thayerova skala za procjenu aktivacije ADACL [Thayer's Activation-Deactivation Adjective Check List, in Croatian]. In: Lacković-Grgin K, Proroković, Ćubela V, Penezić Z, editors. Zbirka psihologijskih skala i upitnika. Zadar: Filozofski fakultet u Zadru; 2002. p. 54-8.
20. Hunter S, Schraer R, Landers DM, Buskirk ER, Harris DV. The effects of total oestrogen concentration and menstrualcycle phase on reaction time performance. Ergonomics 1979;22:263-8

21. Wuttke, W. Circulating hormones, EEG and performance in psychological tests of women with and without oral contraceptives. Psychoneuroendocrinology 1975;1:141-51.

22. Parlee MB. Menstrual rhythm in sensory processes: a review of fluctuations in vision, olfaction, audition, taste and touch. Psychol Bull 1983;93:539-48.

23. Navarrete-Palacios E, Hudson R, Reyes-guerrero G, GuevaraGuzmán R. Lower olfactory threshold during the ovulatory phase of the menstrual cycle. Biol Psychol 2003;63:26979.

24. Söderberg K, Sundström Poromaa I, Nyberg S, Bäckström T, Nordh E. Psychophysically determined thresholds for thermal perception and pain perception in healthy women across the menstrual cycle. Clin J Pain 2006;22:610-6.

25. Fillingin BR, Maixner W, Girdler SS, Light KC, Harris MB, Sheps DS, Mason GA. Ichemic but not thermal pain sensitivity varies across the menstrual cycle. Psychosom Med 1997;59:512-20.

26. Hampson E. Variations in sex-related cognitive abilities across the menstrual cycle. Brain Cogn 1990;14:26-43.

27. Hromatko I. Utjecaj estrogena na shvaćanje prostornih odnosa, perceptivnu brzinu i fine motoričke sposobnosti [Influence of estrogen on spatial abilities, perceptual speed and fine motor skills, in Croatian]. Suvremena psihologija 2001;4:61-71.

28. Charitidi K, Frisina RD, Vasilyeva N, Zhu X, Canlon B. Expression patterns of estrogen receptors in the central auditory system change in prepubertal and aged mice. Neuroscience 2010;170:1270-81.

29. Al-Mana D, Ceranic B, Djahanbakhch O, Luxon LM. Hormones and the auditory system: a review of physiology and pathophsiology. Neuroscience 2008;153:881-900.

30. Walpurger V, Pietrowsky R, Kirschbaum C, Wolf OT. Effects of the menstrual cycle on auditory event-related potentials. Horm Behav 2004;46:600-6.

31. Baker FC, Waner JI, Vieira EF, Taylor SR, Driver HS, Mitchell D. Sleep and 24 hour body temperature: a comparison in young men, naturally cycling women and women taking hormonal contracpetives. J Physiol 2001;530:565-74

32. Hampson E, Young EA. Methodological issues in the study of hormone-behaviour relations in humans: Understanding and monitoring the menstrual cycle. In: Becker JB, Berkley KJ, Geary N, Hampson E, Herman JP, Young E, editors. Sex differences in the brain: from genes to behaviour. New York (NY): Oxford University Press; 2008. p. 63-78.

33. Zajdel R, Nowak D. Simple and complex reaction time measurement. A preliminary evaluation of new approach and diagnostic tool. Comput Biol Med 2007;37:1724-30.

34. Colzato LS, Hertsig G, van den Wildenberg WPM, Hommel B. Estrogen modulates inhibitory control in healthy human female: evidence from the stop-signal paradigm. Neuroscience 2010;167:709-15. 


\section{Sažetak}

\section{PROMJENE BAZALNE TJELESNE TEMPERATURE I VREMENA JEDNOSTAVNE REAKCIJE} TIJEKOM MENSTRUALNOG CIKLUSA

Estrogeni i progesteron moduliraju neuralne funkcije preko svojih receptora smještenih u različitim dijelovima živčanog sustava, kao i djelovanjem na različite neurotrasmiterske sustave. Prijašnja su istraživanja pokazala ciklične promjene razine aktivacije i učinka u različitim zadacima tijekom menstrualnog ciklusa. Cilj ovog istraživanja bio je ispitati mogu li se promjene vremena reakcije na svjetlost i zvuk povezati s promjenama bazalne tjelesne temperature i subjektivnim procjenama opće i visoke aktivacije tijekom faza menstrualnog ciklusa s visokim (preovulatorna i srednja lutealna faza) i niskim razinama (menstrualna i rana folikularna faza) estrogena i progesterona.

Ispitivanje je uključivalo mjerenja bazalne tjelesne temperature, vremena jednostavne reakcije na svjetlo i zvuk te samoprocjene razine opće i visoke aktivacije u menstrualnoj, ranoj i kasnoj folikularnoj te lutealnoj fazi na uzorku od 19 ispitanica s regularnim menstrualnim ciklusima.

Dobiveni su rezultati pokazali nižu bazalnu tjelesnu temperaturu u fazama niskih razina spolnih hormona, dok su procjene razine aktivacije uputile na relativno stabilnu razinu opće i visoke aktivacije tijekom menstrualnog ciklusa. Sličan obrazac promjena dobiven je za vremena reagiranja u vidnom i slušnom modalitetu. Kraća vremena reagiranja dobivena su u fazama visokih razina spolnih hormona, dok faze niskih razina spolnih hormona karakterizira i duže vrijeme reakcije.

KLJUČNE RIJEČI: lista AD-ACL, razina aktivacije, reakcija na svjetlost $i$ zvuk, spolni hormoni

\section{CORRESPONDING AUTHOR:}

Nataša Šimić, Ph.D.

Department of Psychology

University of Zadar

Obala kralja Petra Krešimira IV.2

23000 Zadar, Croatia

E-mail:nsimic@unizd.hr 